\title{
DRUGS USED IN THE TREATMENT OF WOMEN WITH BREAST CANCER TREATED AT A BRAZILIAN REFERENCE HOSPITAL
}

\author{
${ }^{1}$ Cristina Albuquerque Douberin, ${ }^{2},{ }^{*}$ Liniker Scolfild Rodrigues da Silva, ${ }^{3}$ Ketilly Rayane do \\ Amaral Silva, ${ }^{4}$ Edivaldo Bezerra Mendes filho, ${ }^{5}$ Wildin da Silva Rodrigues, ${ }^{6}$ Maria Beatriz \\ Magalhães de Oliveira, ${ }^{7}$ Álvaro Jones Gomes da Silva, ${ }^{8}$ Obimaciliana Maria da Silva Amadeu, \\ ${ }^{9}$ Katyane Melissa Silva dos Santos, ${ }^{10}$ Fernanda Barbosa dos Santos, ${ }^{11}$ Juliana Barbosa Ferraz, \\ ${ }^{12}$ Jackeline Soares dos Santos and ${ }^{13}$ Nazir Ester de Oliveira Bezerra.
}

${ }^{1}$ Nurse, Master in Nursing, University of Pernambuco/State University of Paraíba (UPE/UEPB), Recife, Pernambuco (PE)/Campina Grande, Paraíba (PB), Brazil; ${ }^{2}$ Nurse, Obstetric Nursing Specialist in the Residence modality by the Nossa Senhora das Graças Nursing College (FENSG)/University of Pernambuco (UPE). Resident in the Collective Health Residency Program by the College of Medical Sciences (FCM)/UPE. Recife, Pernambuco

(PE), Brazil; ${ }^{3}$ Post-graduate student in Urgency, Emergency and Intensive Care Unit (ICU) at the Center for Teaching and Research in Medical Emergencies (CEPEM).Maceió, Alagoas (AL), Brazil; ${ }^{4}$ Doctor, University of Pernambuco (UPE). Recife, Pernambuco (PE), Brazil; 5Specialist in Family and Community Health at SUS open

University (UNASUS).Recife, Pernambuco (PE), Brazil; ${ }^{6}$ Nursing Academic, Faculty of Escada. Escada, Pernambuco (PE), Brazil; 7 Physiotherapy Academic, Brazilian University Center - UNIBRA. Recife, Pernambuco

(PE), Brazil; ${ }^{8}$ Nursing Academic, Brazilian University Center - UNIBRA. Recife, Pernambuco (PE), Brazil

${ }^{9}$ Nursing Academic, Brazilian University Center - UNIBRA. Recife, Pernambuco (PE), Brazil; ${ }^{10}$ Specialist in Emergency and ITU, Higher Education Foundation of Olinda (FUNESO), Olinda, Pernambuco (PE), Brazil; ${ }^{11}$ Nurse at the AgamenomMagalhães Hospital. Recife, Pernambuco (PE), Brazil; ${ }^{12}$ Nurse, Integrated Faculties of Vitória de Santo Antão (FAINTVISA). Vitória de Santo Antão, Pernambuco (PE), Brazil; ${ }^{13}$ Specialist in Health of the Ederly, Institute of Biological Sciences, University of Pernambuco (UPE). Recife, Pernambuco (PE), Brazil

\section{ARTICLE INFO}

\section{Article History:}

Received $30^{\text {th }}$ April, 2021

Received in revised form

$20^{\text {th }}$ May, 2021

Accepted $18^{\text {th }}$ June, 2021

Published online $25^{\text {th }}$ July, 2021

\section{Key Words:}

Breast Neoplasms,

Pharmacological Treatment, Drug-Related Side Effects,

Adverse Reactions.

\begin{abstract}
The aim of this study was to identify the main symptomatic and chemotherapy medications used to treat women with breast cancer at Hospital do Cancer de Pernambuco; state of Pernambuco, Brazil. This was a descriptive, cross-sectional study, with a quantitative approach. Three hundred and seventeen women participated in the survey, who were interviewed in an outpatient clinic unit specialized in Mammary Pathology at Hospital do Cancer de Pernambuco, where, after consenting, they answered a questionnaire related to their clinical treatment. The data were described through the analysis (absolute numbers), isolated percentages, and intervals; then these data were demonstrated through tables. The results identified the medications that are part of participants' chemotherapy regimen, the main ones being Paclitaxel, Cyclophosphamide, and Doxorubicin.It was possible to notice that women used medications before chemotherapy, where the main ones are: Dexamethasone and Ondansetron.It was also observed that 107 women use other medications, in addition to those already mentioned, such as antihypertensives and antidiabetics.
\end{abstract}




\section{INTRODUCTION}

Cancer occurs when there are changes in cell division, generating cells with disordered multiplication capacity, due to external and internal factors, ranging from everyday habits to genetic factors.Therefore, these changes in the organism favor a high incidence in the population (Santana et al., 2017; Reis et al., 2016), becoming a universal public health problem (Elias, 2014).Among all malignancies, except non-melanoma skin cancer, breast cancer is the most prevalent in women and has been the highest mortality rate worldwide (Trufelli et al., 2008; Leite et al., 2011). Although breast cancer is identified as cancer with a satisfactory prognosis, when diagnosed and treated properly, mortality rates are still high in Brazil, confirming the probability that the disease continues to be diagnosed in advanced stages (Silva; Albuquerque; Leite, 2010; Souza et al., 2017). Among the treatments available for breast cancer, there is radiotherapy, hormone therapy, immunotherapy, and chemotherapy, the center of the present study, which shows progress in the control and cure of cancer, whether in the neoadjuvant or adjuvant modality.It works with a combination of several agents with differentiated mechanisms of action; this combination produces a potentiated biological effect, aiming at a more effective response, delay in cellular mutations, and a lower incidence of side effects (Melo et al., 2002; Silva; Albuquerque; Leite, 2010; Silva; Carlotto; Rotta, 2018). The most used drugs in the treatment of breast cancer are anthracyclines (e.g., epirubicin and doxorubicin), and taxanes (e.g., paclitaxel and docetaxel).Administered intravenously or orally, with a duration that varies from three to six months (Gabriel et al., 2017; Dagnoni et al., 2016).

Many agents have specific actions in the cell cycle, affecting not only malignant cells, but also healthy ones, favoring the appearance of side effects, such as nausea, vomiting, anemia, alopecia, leukopenia, loss of appetite, among others (Brateibach et al., 2013; Ferreira; Franco, 2017).Therefore, clinical support treatment is important in the treatment of cancer, where it lists several medications to prevent side effects.Enabling greater adherence to cancer treatment and improving quality of life (Franca et al., 2015). In Pernambuco, the Hospital do Cancer de Pernambuco (HCP) is one of the reference hospitals to diagnose and provide oncology necessary assistance, enabling services in order to meet the demand of women for early diagnosis and adequate treatment, aiming to promote mortality reduction (Gurgel, 2011). Therefore, the study aims to identify the main symptomatic and chemotherapy medications used to treat women with breast cancer at Hospital do Cancer de Pernambuco.

\section{MATERIALS AND METHODS}

This is a descriptive, cross-sectional study with a quantitative approach. This study was carried out in the Ambulatory Unit of a specialized clinic in Mammary Pathology of the Hospital do Câncer de Pernambuco (HCP), from September to November 2015. The sample was calculated based on the proportion estimate since it was intended to identify it for the number of women with breast cancer undergoing chemotherapy. Considering that the monthly average of patients with breast cancer undergoing chemotherapy at HCP was $1800(\mathrm{~N})$ and some constant statistical values, such as the $95 \%$ confidence level $(z=1.96)$ and the error $(e)$ or $(d)$ of $5 \%$, a sample (n) of 317 patients was obtained, using a finite population as a reference.

$$
\mathrm{n}=\frac{\mathrm{Z}^{2} \cdot \mathrm{p} \cdot \mathrm{q} \cdot \mathrm{N}}{\mathrm{d}^{2}(\mathrm{~N}-1)+\mathrm{Z}^{2} \cdot \mathrm{p} \cdot \mathrm{q}}
$$

As inclusion criteria, female patients with breast cancer, undergoing outpatient chemotherapy at HCP, aged 18 years and over, and with communication skills for reading and writing comprehension were considered. As exclusion criteria, there were female patients undergoing treatment different from chemotherapy.
The data collection procedure was carried out as follows: the Informed Consent Form (ICF) was delivered, read, and explained to each of the 317 women at the time when they were undergoing chemotherapy at the HCP outpatient clinic. When a woman accepted to participate in the research, the form was signed, showing her agreement and, immediately afterwards, the collection instrument with information about her clinical treatment was responded.

The data collected from the clinical profile were described through the analysis of their frequencies (absolute numbers) and isolated and interval percentages in which they were present in the study population, and were demonstrated through tables. For some variables in these profiles, averages, standard deviation (SD), and minimum and maximum values were also presented. This study corresponds to an excerpt from a Master's dissertation authored by Cristina Albuquerque Douberin, which was submitted to and approved by the Research Ethics Committee of the Pernambucan Society for Combating Cancer under CAAE $\mathrm{n}^{\mathrm{o}}$ 45583415.0.3001.5205; and defended by the author by the Associate Nursing Graduate Program of UPE/UEPB, in May 2016.

\section{RESULTS}

Questionnaires referring to the clinical treatment of 317 women were evaluated, where it was possible to perceive that the use of medications administered in pre-chemotherapy was a common situation for all interviewees, with emphasis on Dexamethasone/ Decadron (99.7\%) and Ondansetron/ Zofran (95.3\%), shown in table 1. Table 2 shows the classes of drugs that are administered in the chemotherapy regimen itself, it is noted the prevalence of Taxol/Paclitaxel (50.2\%), Cyclophosphamide (32.5\%), and Doxorubicin (28.4\%).

It was also possible to observe the usual use of other medications in addition to pre-chemotherapy and/or chemotherapy for other diseases or associated conditions, where it was shown that $107(33.8 \%)$ women reported using it. Thus, the emphasis of the medications used was on antihypertensive drugs, indicated by $86.9 \%$ of the 107 who use other drugs and antidiabetics, indicated by $44.9 \%$ of those who claim to consume drugs in addition to pre-chemotherapy and/or chemotherapy. These results are shown in tables 3 and 4, respectively.

Table 1. Medications administered before chemotherapy. Recife PE Brazil, 2015. $(n=317)$

\begin{tabular}{lll}
\hline Type of pre-chemotherapy medication & Frequency & Percentageof cases \\
\hline Dexamethasone/Decadron & 316 & 99,7 \\
Ondansetron/Zofran & 302 & 95,3 \\
Ranitidine/Antak & 170 & 53,6 \\
Diphenhydramine & 161 & 50,8 \\
\hline
\end{tabular}

Source: Ownelaboration.

Note: Open question. Each woman can indicate more than one medication.

Table 2. Medications administered in chemotherapy. Recife, PE, Brazil, 2015. $(n=317)$

\begin{tabular}{lll}
\hline Typeofchemotherapymedication & Frequency & Percentageof cases \\
\hline Taxol/Paclitaxel & 159 & 50,2 \\
Cyclophosphamide & 103 & 32,5 \\
Doxorubicin & 90 & 28,4 \\
5-Fluorouracil & 42 & 13,2 \\
Docetaxel/Taxotere & 33 & 10,4 \\
Adriblastine & 27 & 8,5 \\
Enduxan & 24 & 7,6 \\
Carboplatin & 07 & 2,2 \\
Gemzar & 06 & 1,9 \\
Cisplatinum & 06 & 1,9 \\
Metrotexate & 02 & 0,6 \\
\hline urce: Ownelaboration. &
\end{tabular}

Note: Open question. Each woman can indicate more than one medication 
Table 3. Frequency of women using other medications, Recife, PE, Brazil, 2015 (n. = 317)

\begin{tabular}{lll}
\hline $\begin{array}{l}\text { Do you use any medication in } \\
\text { addition to pre-chemo and chemo? }\end{array}$ & Frequence & Percentageof cases \\
\hline Yes & 107 & 33,8 \\
No & 210 & 66,2 \\
Total & 317 & $100 \%$ \\
Source: Ownelaboration. & &
\end{tabular}

Table 4. Frequencies of other classes of medications taken, Recife, PE, Brazil, 2015. (n. = 107)

\begin{tabular}{lll}
\hline Other medicationstaken & Frequency & Percentageof cases \\
\hline Anti-hypertensive & 93 & $86,9 \%$ \\
Anti-diabetics & 48 & $44,9 \%$ \\
Antidepressants/Anxiolytics & 28 & $26,2 \%$ \\
Antilipemic & 6 & $5,6 \%$ \\
Variousmedications & 52 & $48,6 \%$ \\
\hline
\end{tabular}

Source: Ownelaboration. Note: Open question. Each woman can indicate more than one medication.

\section{DISCUSSION}

The discovery and previous initiation of cancer treatment are associated with an increase in the cure rate of patients with breast cancer (Reis et al., 3016), as the initiation of treatment late generates a harmful survival (Souza et al., 2017). The planning of therapeutic schemes considers the profile of the drugs, aiming to provide the optimization of the action of chemotherapy, improving the effectiveness, and reducing the appearance of adverse effects (Silva; Carlotto; Rotta, 2018). This study shows that all patients used chemotherapy drugs, as well as those administered before chemotherapy. The most commonly used drugs in the chemotherapy regimen of the hospital in question are Taxol/Paclitaxel $(50.2 \%)$, Cyclophosphamide (32.5\%), Doxorubicin (28.4\%), 5-Fluorouracil (13.2\%) and Docetaxel/Taxotere (10.4\%) (Table 2). Ishikawa, Derchain, and Thuler (2005) found that Cyclophosphamide and 5Fluorouracil were the most used drugs in chemotherapy in their study. Lôbo et al. (2014) identified increased use of Docetaxel, Doxorubicin, and Cyclophosphamide. Gozzo et al. (2013), Silva (2013), and Gonçalves (2013) also identified similar drugs of choice in their patients' chemotherapy regimen, such as Docetaxel, Cyclophosphamide, and 5-Fluorouracil.

It is clear, then, that the most used chemotherapy regimens for women with breast cancer, both in the present study and in those cited in the context, are in accordance with the drugs recommended by the current protocol of the National Comprehensive Cancer Network (NCCN) (2011); which is mainly composed of Doxorubicin, Cyclophosphamide and Paclitaxel/Taxol (Gonçalves, 2013). Chemotherapeutic drugs cause adverse effects, which are related due to their non-specificity by tumor cells and the cytotoxic actions in normal cells, which is more prevalent in hematopoietic tissue cells, germ tissue, hair follicle, and gastrointestinal lining (Gozzo et al., 2013). A study showed that the most frequent adverse effects are nausea and vomiting, (Franca et al., 2015), where about $50 \%$ of cancer patients will suffer from this effect during the treatment period.And chemotherapy drugs in their entirety have emetogenic potential, which varies in intensity. The potential of the most used drugs in breast cancer treatment protocols are: high (above 90\%): cyclophosphamide (above $1500 \mathrm{mg} / \mathrm{m} 2$ ) and cisplatin; moderate (around 30 to 90\%): cyclophosphamide (below $1500 \mathrm{mg} / \mathrm{m} 2$ ), epirubicin, doxorubicin; low (from 10 to 30\%): 5-fluouracil, paclitaxel, docetaxel, methotrexate, liposomal doxorubicin, gemcitabine, trastuzumab and minimal (below 10\%): vinorelbine (Gozzo et al., 2013). Thus, clinical support is necessary for the control of side effects, where patients are offered the available resources, with the purpose of ensuring the quality of life and ensuring the success of treatment (Franca et al., 2015).
This study presents the most used medications before chemotherapy, which are Dexamethasone/Decadron (99.7\%), followed by Ondansetrone/Zofran (95.3\%), and Ranitidine/Antak (53.6\%).Including the presence of 107 women who reported using other medications, with predominance, in this case, for antihypertensive drugs $(86.9 \%)$ and antidiabetics (44.9\%). Gozzo et al. (2013) stated that, among the antiemetic drugs used before chemotherapy, Ondansetron and Dexamethasone were used in all cases, followed by Ranitidine $(81.8 \%)$, which is in line with the results of this study. They also pointed out that Omeprazole was one of the most widely used medications by their patients (47.8\%).Still, regarding other medications, Silva (2013) identified that the antihypertensive, antidiabetic and antidepressant classes were the most used by patients in his work, a fact that is similar to the findings of this study.

\section{CONCLUSION}

The chemotherapy regimen used in the reference hospital in Pernambuco is in line with what is found in the literature, where the main drugs are Paclitaxel, Cyclophosphamide, and Doxorubicin.It is also noted that all respondents were using antiemetic medications before chemotherapy, with Dexamethasone, Ondansetrone, and Ranitidine being the most used; as well as the use of other medications in a small portion of patients, with a predominance of antihypertensive and antidiabetics.

\section{REFERENCES}

Brateibach, V. et al. 2013. Sintomas de pacientes em tratamento oncológico. Revista ciência \& saúde, porto alegre, 6, 2, pp.102109.

Dagnoni, C. et al. 2016. Perfil clínico e tumoral de pacientes submetidas a tratamento neoadjuvante de câncer de mama no hospital erasto gaertner. Rev bras mastologia, 264, pp.158-63.

Elias, Thaís cristina. Efeito da quimioterapia na capacidade funcional de mulheres com câncer ginecológico, câncer de mama e doença trofoblástica gestacional no serviço de oncologia de um hospital público. 2014. 120f. Dissertação mestrado em atenção à saúde programa de pós-graduação stricto sensu em atenção à saúde, universidade federal do triângulo mineiro, uberaba, 2014.

Ferreira, R.G.R.; Franco, L.F.R. 2017. Efeitos colaterais decorrentes do tratamento quimioterápico no câncer de mama: revisão bibliográfica. Revista da universidade vale do rio verde, três corações, 15,2, pp.633-638.

Franca, M.S. et al. 2015. Avaliação da aderência à diretriz de cuidados para náuseas e vômitos induzidos por quimioterapia. Einstein são paulo [online],13,2, pp.221-225.

Gabriel, G.H.; nepomuceno, L.L.; pimenta, V.S.C.; araújo, e.g. 2017. Quimioterapia, hormonioterapia e novas alternativas de tratamento do adenocarcinoma mamário. Enciclopédia biosfera, centro científico conhecer - goiânia, 14, 26, pp.583-608.

Gonçalves, L.L.C. 2013. Trajetória de mulheres com câncer de mama: dos sinais e sintomas ao tratamento. $145 \mathrm{f}$. Tese doutorado - escola de enfermagem de ribeirão preto, universidade de são paulo, ribeirão preto.

Gozzo, T. O. et al. 2014. Ocorrência e manejo de náusea e vômito no tratamento quimioterápico em mulheres com câncer de mama. Rev. Gaúcha enferm, 35,3, pp. 117-123.

Gozzo, T.O. et al. 2013 náuseas, vômitos e qualidade de vida de mulheres com câncer de mama em tratamento quimioterápico. Rev. Gaúcha enferm;34, 3, pp.110-116.

Gurgel, Marcela Maia Santos. 2011. Câncer de mama: estágio no momento do diagnóstico em mulheres residentes do recifepernambuco. Monografia saúde coletiva - programa de residência multiprofissional em saúde coletiva do departamento de saúde coletiva, centro de pesquisas aggeu magalhães, fundação oswaldo cruz, recife.

Ishkawa, N. M.; Derchain, S. F. M.; Thuler, L. C. F. 2005. Fadiga em pacientes com câncer de Mama em tratamento adjuvante. Revistabrasileira de cancerologia, 51, 4, pp.313-318. 
Leite, f.m.c.; bubach, s.; amorim, m.h.c.; castro, d.s.; primo, c.c. 2011. Mulheres com diagnóstico de câncer de mama em tratamento com tamoxifeno: perfil sociodemográfico e clínico. Revista brasileira de cancerologia; 57, 1, pp. 15-21.

Lôbo, S. A. Et al. 2014. Qualidade de vida em mulheres com neoplasias de mama em quimioterapia. Acta paul. Enferm, 27, 6, pp.554-559.

Melo, E.M.; araujo, T.L.; oliveira, T.C.; almeida, D.T. 2002. Mulher mastectomizada em tratamento quimioterápico: um estudo dos comportamentos na perspectiva do modelo adaptativo de roy. Revista brasileira de cancerologia, 48, 1, pp. 21-28.

National comprehensive cancer network ncen. 2011. Clinicalpracticeguidelines in oncology ncen guidelines $^{\text {tm }}$ cancerrelated-fatigue, version 1 .

Reis, F.P. et al. 2016. Perfil epidemiológico das pacientes com câncer de mama atendidas em uma unidade de saúde em são francisco do conde, ba. Rev. Ciênc. Méd. Biol., salvador, 15, 2, pp.144-150.

Santana, p.k.s; rodrigues, i.p.; paciencia, g.p.; paz, p. 2017. Comparativo de expectativas de casos de câncer de mama em mulheres no brasil para o ano de 2016. Revista enfermagem e saúde coletiva, 1,1 , pp. $13-25$.
Silva, A.A.; carlotto, J.; rotta, I. 2018. Padronização da ordem de infusão de medicamentos antineoplásicos utilizados no tratamento dos cânceres de mama e colorretal. Einstein são paulo; 16, 2, erw4074.

Silva, C.B.; albuquerque, V.; leite, J. 2010. Qualidade de vida em pacientes portadoras de neoplasia mamária submetidas a tratamentos quimioterápicos. Revista brasileira de cancerologia, 56, 2, pp.227-236.

Silva, M. D. 2013. As repercussões corporais vivenciadas pela mulher com câncer de mama decorrentes do tratamento quimioterápico: uma análise à luz da teoria de sistercallista roy. $115 f$. Dissertação mestrado -faculdade de enfermagem da universidade do estado do rio de janeiro, rio de janeiro.

Souza, N.H.A. et al. 2017. Câncer de mama em mulheres jovens: estudo epidemiológico no nordeste brasileiro. Sanare, sobral, 16, 2, pp.60-67.

Trufelli, D.C. et al. 2008. Análise do atraso no diagnóstico e tratamento do câncer de mama em um hospital público. Rev assoc med bras; 54, 1, pp.72-6. 